\title{
Franchise Entrepreneurial Leadership: Leadership Dominance and Its Level of Success at the Franchisee Level
}

\author{
John C. Cary \\ SUNY New Paltz
}

Entrepreneurs within the United States are plagued with high incidences of failure in the early years of business. What seems to be lacking in these organizations is leadership and the type of leadership style that leads to greater levels of success. This quantitative study answered the following research question: Is there a significant relationship between the various degrees of success of selected national franchises and the assessed leadership styles of their leaders? The leadership styles assessed were transformational and transactional. A random sample of 50 franchise leaders throughout the United States was selected and the data was collected from a Multifactor Leadership Questionnaire. The findings showed that there was a significant difference in styles, indicating that transformational leadership delivers greater levels of success at the franchisee level.

Keywords: entrepreneurship, leadership, franchise, success, small business

\section{INTRODUCTION}

With small business enterprises being the backbone of the country, it is important to understand the statistics surrounding the success and failure rates of these organizations. It is commonly believed that each year more than one million new businesses are formed in the United States under a variety of structures, and of those, $40 \%$ fail within the first year, and $80 \%$ fail after five years. Of the $20 \%$ that manage to survive the five-year mark, $80 \%$ are gone within 10 years (Gerber, 1995). When new entrepreneurs aspire to start an enterprise or company, they have two basic business opportunities to explore. The first is starting out as an independent business person without ties or affiliations to a corporate or regional branch office. The second is to buy into an existing business with already established business practices and procedures. This second choice is known as a franchise system.

Both choices can be equally risky and carry a high probability of failure. However, Stanworth, Purdy, English, and Willems (2001) wrote that the failure rate in independent businesses is not quite as high as the public might surmise. The study noted that, within the first six years, failure rates were at $66 \%$ and not the $80 \%$ rate commonly cited. In fact, they stated that the figures might be as low as $35 \%$ in the construction industry and $47 \%$ in the manufacturing industry. Even at these figures, the numbers are staggering. Stanworth et al. (2001) explained the component that can reduce the failure rate is measured by how quickly a company begins its operation; thus a franchise model with systems and processes already in place might be a viable solution for an entrepreneur.

Unfortunately, research indicates that the franchise option does not show any more promise than the independent businesses. Two studies conducted using data from 1980 through 1992 showed only $29 \%$ of 
the franchise stores or businesses studied were still operating after 12 years. Lafontaine and Shaw (1997) looked at 2,524 businesses over this same time span and concluded that $583(23 \%)$ franchise systems were still operational. This assumes that more franchise systems left the market than entered. Additionally, they tracked 138 franchise systems beginning in 1983 and discovered approximately $25 \%$ lasted for at least 10 years.

One explanation for failure was the rapid attrition rate of the franchisor. Within four years, half of the franchisors closed their doors, leaving the franchisees without a business. Lafontaine and Shaw's findings complicated understanding the failure rate of franchisees, because the closing of a franchisor is an uncontrollable variable from the perspective of the franchisee. Nonetheless, it is clear from the statistics that both franchise owners and small business entrepreneurs are not doing as well as they should. Although the two studies provided insight into one possible reason for the failure of franchises, there was little mention of leadership as part of the equation and the impact leaders have on franchises.

O'Grady and Malloch (2011) argued that organizations needed leaders who looked ahead, saw changes or signposts, and informed others of the forthcoming changes. Followers look to their leaders for guidance in the complexities of a changing world. Despite the enthusiasm entrepreneurs demonstrate, along with the desire for independence and business ownership, much of the current literature tells a different story of the life of an entrepreneur. Small businesses, independent and franchises alike, struggle to survive in the marketplace during the formative years. The research study looked at the role leadership plays within business ownership and whether particular leadership styles were pervasive and influenced success in the franchise.

It would make sense that, with all the literature in the field of leadership, the role of leadership would have proven its value to the success of an organization. Kouzes and Posner (2007) explained, "Leadership is everyone's business" (p. 339), and because it is everyone's business, Kouzes and Posner suggested that leadership can be learned and that individuals can make a difference within an organization. One way to understand the role of the individual is through what Maier and Zenovia (2011) called "intrapreneurship". "The intrapreneur is the revolutionary inside the organization who fights for change and renewal from within the system. This may give rise to these conflicts and transform them into positive aspects for the company" (Maier \& Zenovia, 2011, p. 972).

Kouzes and Posner (2007) stated that, "leadership can happen anywhere, at any time" (Kouzes \& Posner, p. 8). Leadership is demonstrated in public, private, and government sectors. The literature on leadership practice has focused on schools, corporations, government, and other entities, but it has left out small businesses, franchises, and entrepreneurs. Specifically, the literature did not show the influence leadership has on franchise businesses and entrepreneurship. Given the high failure rate of small businesses and entrepreneurial organizations, there was a need to know if leadership styles and practices, in fact, influenced success.

Northouse (2010) asserted that leadership and management have some noteworthy differences. He argued that leadership dates back as far as Aristotle, and the study of management was evident in the $20^{\text {th }}$ century. Much of the literature identified management as a major contributor to business failure and conflict, and this is looked at repeatedly through the framework (Shane, 1998). Shane, of Case Western Reserve University, has been one of the most prolific researchers who studied the Agency Theory (Shane, 1998), which suggests that a manager's lack of ownership in a business may be problematic. He has written extensively on entrepreneurship, organizational behavior, and management science and he explained that while franchising solves many of the problems linked to the Agency Theory, it is not a fool-proof solution. An emphasis on leadership rather than management provided additional insight into many of the problems faced by franchise owners. As such, the review of the literature investigated many of the problems faced by franchise owners and indicated that leadership has not yet been examined as a means of mitigating the issues. 


\section{LITERATURE REVIEW}

With so many small businesses starting out in the United States, why do so many fail in the formative years? Northouse (2010) detailed the various types of leadership styles and approaches in practice today, demonstrating the value leadership plays in an organization's health and performance. Two of the leadership styles described by Northouse are transformational and transactional.

With the endorsement of many chief executive officers (CEOs), prominent leaders, and top organizations in the field, Northouse (2010) noted that transformational leaders are in the forefront promoting and respecting the sentiments of others and delivering a vision for the future of the people. This form of leadership has been shown to have an influence on followers, providing them with the tools to accomplish tasks normally outside of their abilities (Northouse, 2010).

A philosophically different, yet sometimes complimentary, style of leadership includes transactional leadership. Northouse described transactional leadership as a management style that uses a reward system to either motivate followers or help promote and advance the leader's agenda. Avolio (2011) stated that while transactional leadership forms a foundation for transformational leadership, it does not help promote an individual's full potential and, thereby, makes one less creative and innovative. These two leadership styles together formed the theoretical framework for the study.

A review of the literature indicates a lack of information on the needed leadership in franchise entrepreneurs. There is extensive literature on leadership skills and their value in organizations, but understanding leadership in the context of franchises has limited literature sources. Clearly, with the high failure rate of small businesses, something is missing in leadership training and awareness. The study explored the proclivity toward one of the leadership approaches practiced in varying degrees of successful franchises to close this gap and add new knowledge to the existing body of literature. Specifically, this study examined leaders in an entrepreneurial franchise system and determined whether the success of the franchises was related to the leaders' transformational or transactional leadership approach.

The literature review highlights four major areas and demonstrates the importance each plays in understanding the gravity of the leadership problem facing entrepreneurs in both franchise systems and independent businesses. The areas include: (a) entrepreneurship, (b) the value of leadership in organizations, (c) the emerging field of franchising, and (d) transformational and transactional leadership. The literature review looks at some areas of research that impact and influence entrepreneurs in their quest for success. For example, the literature review answers the question of what is being done to make the road to business ownership and self-employment a possibility for a greater number of individuals. By considering the behavioral differences that generate opposing results, the literature review illustrates why some enterprises succeed and others fail. The study also looked at franchise systems as a viable solution for some aspiring entrepreneurs.

\section{Entrepreneurship}

As suggested by Bann (2009), an entrepreneur looks for opportunity in self-employment venues despite the ramifications it has on the individual's personal life. Bann noted that entrepreneurs want to put themselves in positions where they can dictate the situation as well as look for challenges that can enhance their self-esteem.

Bann's study of entrepreneurs was a phenomenological investigation on what it takes to be an entrepreneur and how entrepreneurs differentiate themselves. The study used the Trait Theory to explain that some people are inherently predisposed to entrepreneurship and possess the behaviors of commitment, drive, and perseverance. The qualitative methodology involved 18 participants. Each participant needed the following requirements to be part of the study: (a) was the owner of his or her business, (b) worked in a similar industry, (c) company's revenues were less than $\$ 2$ million dollars per year, (d) organization was in business for at least two years of operation, (e) business was profitable or at least achieved a break-even point for one year, and (f) was at least 25 years old.

Analysis of interviews with the entrepreneurs identified four underlying themes (Bann, 2009). First, each participant experienced an ill-fitting situation in either their personal life or working environment. 
This event drove them into the direction of entrepreneurship. Second, each participant maintained a level of self-confidence that afforded them the drive, determination, sustainability, and work ethic to pursue their entrepreneurial endeavors. Third, each shared a desire to go out into their community and the world to teach, communicate, and pass on life lessons to others to affect change in someone's life. The last theme of the research revealed the entrepreneurs' desire to be respected by their community and peers; and receive a positive perception from the public (Bann, 2009)

\section{Leadership}

Leadership is a complex process and is present in many aspects of our lives (Kouzes \& Posner, 2007). They asserted that leaders can reside in many places and can be found in ordinary individuals and in a host of different settings. Northouse (2010) stated, "Leadership is a process whereby an individual influences a group of individuals to achieve a common goal" (p. 3). With the many leadership styles today, Kouzes and Posner (2007) explained the five behavioral indicators that all of these styles embody. They include: (1) model the way, (2) inspire a shared vision, (3) challenge the process, (4) enable others to act, and (5) encourage the heart.

\section{Franchising}

The concept of franchising can be traced to the medieval times, which includes the $5^{\text {th }}$ century and up through the $15^{\text {th }}$ century (Lafontaine and Blair, 2005). Lafontaine and Blair (2005) explained that the sovereign powers of the time, namely, kings, the church, and government, would relegate certain powers and duties to be carried out by groups or individuals. These activities were community based and were to be reported back to the powers in charge. This right to collect taxes or promote local activities was a privilege but with the responsibility of payment back to the sovereign group. A portion of the earnings was paid back to the king for the right of ownership to some activity. The payment was called a royalty; the term still in use today by franchise businesses (Lafontaine \& Blair, 2005).

The term franchise is used in other fields and industries but not in the context meant for this study. The government grants cable companies, through a bidding process, for example, the rights to provide their services in a particular area and for a certain length of time. Professional sports teams are granted rights to represent a city or area in the country. These teams are owned by an individual or group, operating under the name of the team. The arrangements are regulated by professional sports leagues (Dickie, 1992).

Dickie (1992) confirmed that the term franchising became part of the business lexicon in 1959 as a way of conducting business. Lafontaine and Blair (2005) wrote that there are two basic types of franchise systems today. The first, called the traditional, dates back to the $1800 \mathrm{~s}$ when companies sold the rights to individuals or agents to sell their goods and services within a sales territory. The most recognizable company operating under this model was the Singer Sewing Machine Company and the McCormick Harvesting Company. These companies eventually transitioned over to a dealership model, where this is seen today in the automobile, gas station, and soft drinks industry. These companies are referred to as dealers (Lafontaine \& Blair, 2005).

Franchising's History (2010) stated that Midas Mufflers is one of the largest automotive franchises with more than 2,400 franchise stores extending throughout 15 countries. The company started in 1956 and has its primary business in the mufflers, brakes, and tire maintenance business. This would be regarded as a business-systems franchise that must follow certain processes and procedures outlined by the corporate franchisor.

The two primary sources of income for the franchisor include the initial admission fees and the ongoing royalty payments. Watson and Johnson (2010) argued that these royalty payments are really management fees. Lafontaine and Blair (2005) explained it in terms of royalty. The initial fee paid to the franchisor is the admissions payment to become a franchisee. These fees may differ from industry to industry and be affected by the maturity of the franchise system. If the franchise company is not well established, then the fees are likely to be smaller than those franchise companies that have performed well and been in existence for a longer period. The fee is normally based on the size of the franchise territory 
and is relatively small over the life of the franchise. The royalty fee is calculated as a flat fee, percentage of sales, or percentage of gross profit.

\section{Franchisor \& Franchisee}

The major components of a franchise system in today's market include the products and services, the franchisee, and the franchisor. The franchisor is the corporate office and support network, and it is the only entity that legally owns the franchise name. The franchisee is the independent owner of one or more of the franchise stores. McDonald's is a franchise system with the corporate office selling and administering all the stand alone franchise restaurants. They are also the only entity holding the name McDonald's while the local restaurants throughout the country may operate under the name of John Doe's Restaurant, Inc., doing business as McDonald's (Franchising Your Business, 2004).

The relationship between the franchisor and franchisee is very similar to a company with agents under its control. It may also be compared to that of a supervisor who may be the manager of a local store under the direction of the corporate office (Mellewigt, Ehrmann, \& Decker, 2011). This agent/supervisor relationship has been studied extensively by many researchers through what is known as the Agency Theory.

\section{Transformational \& Transactional Leadership}

Avolio (2011) suggested that transformational and transactional leadership are the two most effective forms of leadership. He demonstrated that these styles create what is known as full range leadership (Avolio, 2011). Bass (2003) preceded this when he suggested that transactional leadership is simply an extension of transformational leadership. Avolio (2011) mentioned a discussion he had in one of his workshops with a student who felt the idea of transforming a company is only a theory and it could never happen in their company. He continued to state that, "an attitude that like may actually become the leadership style that is practiced" (p. 135).

Transformational leadership has been shown to possess several strengths, making it the most effective style (Avolio, 2011). This type of leader also displays strength in an attitude toward his or her followers. It is not just about the leader's interests but, rather, the synergy between the leaders and followers and how they relate to each other. Northouse (2010), along with his colleague Bass (2003), understood that transformational leadership provides a foundation for other leadership styles and expands on their key characteristics.

Ling, Simsek, Lubatkin, Lyon, and Veiga (2008), studied transformational leadership at the corporate level to see what influence a CEO could command in a macroeconomic setting. The researchers looked at top management team members (TMT) and their relationship to the CEO. It was suggested that a CEO with transformational leadership skills could provide those entrepreneurial traits to their TMT by promoting product innovation and strategic activities. The more support the CEOs demonstrated toward the top management team members through transformational activity, the more likely the subordinates would deliver to their TMTs. CEOs were shown to have a greater effect on those they directly worked with, rather than the group below TMTs. It was the job of the top management team to deliver leadership to those followers (Ling et al., 2008)

Ismail, Mohamad, Mohamad, Rafiuuddin, and Zhen (2010) suggested there were different indicators of follower outcomes based on the leadership style of their leaders. Depending on the leadership style, procedural, or distributive justices may emerge because of the leader's style. Transformational leadership is grounded in a relational contract between the leader and follower, but the transactional leader delivers what Ismail et al. (2010) call an economic contract. The term transactional leader is derived from the idea of "transaction" implying "you, as the follower, have something I, the leader, want (labor), and I have something you want (money). So let's make an exchange." (Stevens, 2011, p. 37).

Bass (2003) wrote that transactional leadership forms much of the base of what is known as the popular leadership style called transformational. This can evolve from a transactional leader delivering promises to followers and subordinates in the form of rewards and exchanges. If the transactional leader is able to maintain this promise and level of commitment, over time, the leader may earn the trust of his 
followers. This may be a viable strategy, but as Avolio (2011) argued, appeasing each employee and having him or her buy into transactional leadership can be a difficult challenge and may not have the consistent support of followers for the long term.

Bass (2003) explained that transactional leadership precedes the actions of transformational leaders; thus implying one style cannot exist without the other. This notion of integrating transactional and transformational leadership is highlighted as full-range leadership (Avolio, 2011).

Transactional leadership is needed to provide structure, accountability, standards of practice, reward measurements, and goal setting, and it is still popular among personnel managers who must oversee employees who are relating to frontline customers (Morhart et al., 2011). However, there is a point of diminishing return when transactional leadership is discounted, and the style delivers a negative psychological impact on its followers. Bass (1997) argued that some transactions are void of any behavioral influences. Morhart et al. suggested transformational leadership can foster branding behavior by its followers, through the employee's ability to create brand perception from the customer.

\section{Research Questions}

The research study attempted to answer the following questions:

\section{Essential Research Question}

Is there a significant relationship between the various degrees of success of selected national franchisees and the assessed leadership styles of their transformational and transactional leadership as perceived by the leaders? The levels of success were defined by the researcher and the leadership styles were transformational and transactional.

\section{Supporting Research Questions}

There were four questions that were answered as part of addressing the essential research question.

1. Is there a significant relationship between the gender of the franchisee, the degree of success of the franchise, and the dominant leadership style?

2. Is there a significant relationship between the age of the franchisee, the degree of success of the franchise, and the dominant leadership style?

3. Is there a significant relationship between the education of the franchisee, the degree of success of the franchise, and the dominant leadership style?

4. Is there a significant relationship between the size of the franchise, the degree of success of the franchise, and the dominant leadership style?

\section{Success}

For the purposes of this research, success was defined by five traits:

1. The franchise business has operated for at least five years.

2. There was a year-over-year incremental positive-growth pattern for the past five-year period.

3. There was net revenue of $\$ 300,000$ by the end of the fifth year.

4. The shipment requirement from the franchisor was met during the past five years.

5. The franchisee has retained $75 \%$ of its customer base for the past five years.

\section{METHODOLOGY}

The quantitative research design consisted of two primary sets of analysis from data collected using the Multifactor Leadership Questionnaire (MLQ). The data was used to determine whether a participant showed a tendency toward transformational or transactional leadership. Data were collected from franchisees across the United States. In that the targeted research participants are part of a single franchise organization, and fragmented and located in many areas of the country, a qualitative study was not logistically possible within the time constraints of the research process. An online survey, however, offered an appropriate method for this study. 
Data analysis, first, compared the independent variables (transformational and transactional leadership styles) against the mean of the dependent variable (degree of success in franchises) using a ttest. The second analytic component examined the demographics of the sample population (gender, age, education, and size of franchise) in order to determine whether certain demographics showed a correlation between leadership style and success. Descriptive statistics were used to report demographic comparisons between the two leadership groups and their relationship to success and leadership styles.

\section{Research Context}

The franchise organization studied composed of approximately 200 individual franchise sites. The corporate franchisor office is located in the western part of the United States. The company began in the late 1980s with only one office and one franchisee. Its primary services have evolved over time with the expansion of additional franchise units, but its core mission and objective have not changed. The company is a third-party logistics (3PL) agent for other companies such as United Parcel Service (UPS), DHL Worldwide Express (DHL), Yellow Roadway Corp, and 25 additional freight carriers.

The partnership with the listed companies has allowed each franchisee the opportunity to penetrate their local markets, and with leadership and entrepreneurial skills, build and service their own pool of customers in their respective territories. The geographic location and size of each franchise can vary considerably as well as the franchisee's gender, age, level of education, and franchise size. The typical franchise location consists of an office suite located within the franchisee's territory as set by the contract of the franchise agreement. The franchise leaders normally work with inside and outside sales representatives, customer service agents, freight consultants, billing clerks, and managers. To minimize bias, the researcher, a franchise owner and operator, did not participate in the study.

\section{Research Participants}

The research participants were leaders, owners, CEOs, or presidents who are part of the national logistics franchise organization located in the western part of the United States. It included those owneroperators who take on the leadership role within their franchise. The entire population of franchise owners in this system included 200 owner-operators, and the goal of $25 \%$ of the entire population of 200 franchise leaders was the target for this study. The 50 participants were selected without bias to any particular geographical area within the United States.

The information on the franchise leaders was gathered using an online database provided by the franchisor to all franchisees. This information was accessed by the researcher through the company's intranet support website. This list included all franchisees and their corresponding name, telephone number, electronic mail address, name of their franchise entity, and city and state of operation.

A pre-qualifying email was sent to the franchise body of owner-operators to initially determine if they met the requirements for participation in the leadership study. Each franchisee was required to answer yes to the three following questions to qualify as a participant:

1. Are you an active owner?

2. Do you employee at least one person?

3. Have you been a franchisee for at least one year?

With a response rate of less than 50 participants, a second randomly chosen group was selected to complete the deficit. The researcher continued through the initial list of potential participants, randomly choosing the balance needed until 50 respondents agreed to participate.

The franchise leaders who agreed to participate in the study were not compensated but offered the opportunity to receive a confidential email copy of the leadership survey results directly from Mind Garden, Inc.

\section{Instruments Used in Data Collection}

The data collection instrument was the Multifactor Leadership Questionnaire (MLQ) survey. The MLQ was designed to identify leaders' tendencies toward either a transformational or transactional leadership style, rather than classifying them with an absolute leadership style. The MLQ was developed 
by Avolio and Bass (1995) was found to be valid and reliable. A valid instrument is one that delivers what it purports to test, and a reliable instrument reports the same findings after repeating the test several times. Mind Garden, Inc. holds the copyrights to the MLQ survey. The company customized the survey to meet the specific needs of the researcher. The survey contained three sections with a total of 37 questions.

The first section included questions designed for the leader, owner, or president of the franchise office. This form had 28 questions wherein the leader assessed his or her leadership style and behavior toward the followers, employees, and associates in their organizations. Eight of the questions centered on transactional leadership, and 20 focused on transformational leadership. The questions were not categorized in any particular order, giving the instrument further integrity. The survey used ordinal data on a five-point Likert-scale rating format with answers ranging from $0-4$, with 0 meaning "not at all" and 4 meaning "frequently, if not always." Participants completed the survey online, and unlike a manual survey, the online version forced the participants to answer each question before advancing to the next question.

The second section included five questions regarding the degree of success in the leader's franchise organization, as defined within the study. The questions recorded nominal data requiring a "yes" or "no" response, and all five questions needed to be answered with a "yes" or "no" to qualify the leader as a participant.

The last part of the survey included four demographic research questions and used a nominal scale. The demographic questions included gender, age, level of education, and size of the franchise. The instrument prompted the participant to choose from a drop-down menu of demographic choices, with each question providing two options. The instrument asked whether the participant was male or female, greater than or equal to the age of forty, whether the participant was a college graduate, and if the size of their franchise was between 0-3 sales territories and greater than 3 sales territories.

The research involved a quantitative analysis of the relationship of franchise success and the leader's tendency toward a transformational or transactional leadership style in a business-format franchise system. The data collection instrument used a five-point Likert scale. Sub-questions were investigated using demographic data collected at the same time the participants complete the MLQ. The data were collected and processed through the Statistical Package for the Social Sciences (SPSS), a statistics program on a Windows-based system.

Bass and Avolio (1995) noted that transformational and transactional leadership styles are associated with specific influences and behaviors. The questionnaire was divided into different sub-scales for each leadership style. Transformational leadership sub-scales included idealized influence (two parts), inspirational motivation, intellectual stimulation, and individual consideration. Transactional sub-scales included contingent reward and management-by-exception. The MLQ survey yielded statistics on the descriptive data on all participants' responses to the questions and a breakdown of each sub-category. The researcher reported on the mean, median, mode, and standard deviation for each participant in each of the sub-categories.

The second part of the MLQ survey was customized to include five questions relating to the level of success of each participant's franchise. The level of success of the organization was decided based on a combination of yes and no answers to the questions. Each "yes" answer received 1 point, and each "no" answer received zero (0) points. Participants answering "yes" to all five questions were coded with a " 5 " on the success continuum. Participants answering "no" to all five questions were coded with a "0" on the success continuum. All numbers between those ranges were included and coded with the respective numbers $1,2,3$, or 4 .

The third section of the survey included a demographic study of the sample population using nominal data. Participants identified their gender, age range, level of education, and size range of their franchise organization through a series of four questions. Each question had only two choices as a response, allowing the researcher to use a binary coding system of "0" and " 1 " when categorizing each answer. All of the answers classified as male, less than or equal to forty years of age, no college degree, and a franchise territory less than or equal to 3.0 sales territory were coded as a "0" for data analysis purposes. All the answers classified as female, greater than forty years of age, college educated, and a franchise 
territory greater than 3.0 sales territories were coded as a " 1 " for data analysis purposes. Once the researcher finished coding the four demographic categories, the data were uploaded into SPSS along with the data collected in Section 2 of the survey. It included that participant's organization's level of success number. A t-test analysis was then used to determine if there was a significant difference within each demographic category and level of success. This demographic analysis was performed with both leadership styles.

\section{RESULTS}

Survey data were collected from leaders of a logistics franchise organization and responses were processed by a third-party company Mind Garden, Inc., to maintain anonymity. The targeted population was smaller than originally planned due to the number of co-owned franchised units. Identifying the redundant ownership arrangements reduced the population from 200 to 100 franchise leaders. These numbers showed some variance due to the dynamic nature of the systems' franchisee enrollment process and attrition level. However, the variance did not influence the number of qualified participants expected for the research study. Table 1 demonstrates the results of the process used to arrive at the 50 qualified participants.

The 50 qualified participants responded to a three-part online MLQ survey designed to assess a tendency toward a dominant leadership style, determine the franchise level of success, and address four demographic questions regarding gender, age, education, and size of the franchise.

\section{TABLE 1 POPULATION BREAKDOWN}

\begin{tabular}{ll}
\hline Category & Number of Franchise Leaders \\
\hline Qualified Participants & 50 \\
Non-Qualified Participants & 20 \\
Unable to Contact & 10 \\
Qualified, No Response & 4 \\
Qualified, Declined Participation & 2 \\
Survey Not Completed & 4 \\
No Initial Response & 10 \\
Total & 100 \\
\hline
\end{tabular}

In the first section of the survey, the franchise leader answered 28 questions dealing with transformational and transactional leadership. The questions were randomly placed between the two leadership styles. The survey was structured such that each respondent had to provide an answer before advancing to any subsequent question. The instrument used ordinal data on a Likert-scale with answers ranging from $0-4$, with 0 meaning "not at all" and 4 meaning "frequently, if not always." The participants could choose "not sure" if they were unable to give a valid answer. This was recorded as a "blank" on the output data sheet. Six participants answered one question as "not sure" and one participant answered "not sure" to two of the questions.

Each participant answered 20 transformational and eight transactional leadership questions. Each question received an answer between $0-4$ on the Likert scale. The responses to the transformational questions were added and divided by 20 to yield a value on the transformational Likert scale. The same procedure was performed on the eight transactional questions except the total was divided by 8 . For instance, if a participant's score on the transformational questions yielded a total of 60 , then the number was divided by 20 to produce a 3 on the overall transformational Likert Scale.

If the same person scored a 16 on the questions addressing transactional leadership, then the number was divided by 8 to yield a 2 on the transactional Likert Scale. 
All answers recorded as "not sure" were removed from the Likert scale calculation. For example: If a respondent scored a 36 on all the transformational questions and chose "not sure" on two of the questions, the score of 36 was divided by 18 questions instead of 20 questions. Table 2 displays the scores from the 50 participants and only includes participates in the research study.

While the focus of the study was the relationship between levels of success among franchises and the correlation with a dominant leadership style, it is important to understand that many leaders in the study embodied attributes from both transactional and transformational leadership styles. The raw data, without any statistical analysis performed, however, illustrates that the dominant style seems to favor transformational leadership. The transactional leaders, like their counterpart showed traits of transformational leadership, commonly referred to as full-range leadership.

TABLE 2

PARTICIPANTS' AVERAGE LIKERT SCORES FOR LEADERSHIP

\begin{tabular}{llllll}
\hline Participants & Transformational & Transactional & Participants & Transformational & Transactional \\
\hline 1 & 2.65 & 1.25 & 26 & 2.90 & 1.25 \\
2 & 2.90 & 2.38 & 27 & 3.25 & 2.38 \\
3 & 3.75 & 3.50 & 28 & 2.89 & 2.13 \\
4 & 3.50 & 2.38 & 29 & 2.80 & 2.63 \\
5 & 2.70 & 2.50 & 30 & 2.40 & 2.13 \\
6 & 3.55 & 3.13 & 31 & 3.00 & 2.38 \\
7 & 3.40 & 2.88 & 32 & 3.45 & 2.50 \\
8 & 2.90 & 2.88 & 33 & 2.90 & 2.38 \\
9 & 3.55 & 2.00 & 34 & 3.40 & 2.57 \\
10 & 3.20 & 1.75 & 35 & 2.95 & 3.00 \\
11 & 2.40 & 2.13 & 36 & 2.75 & 2.50 \\
12 & 2.35 & 1.88 & 37 & 3.00 & 2.13 \\
13 & 3.30 & 3.25 & 38 & 3.26 & 2.50 \\
14 & 2.65 & 1.63 & 39 & 1.90 & 1.63 \\
15 & 3.10 & 3.63 & 40 & 3.60 & 2.88 \\
16 & 3.85 & 3.38 & 41 & 4.00 & 1.63 \\
17 & 3.20 & 2.25 & 42 & 2.70 & 2.00 \\
18 & 2.60 & 1.75 & 43 & 3.05 & 2.00 \\
19 & 2.53 & 2.38 & 44 & 2.25 & 2.25 \\
20 & 3.65 & 2.75 & 45 & 2.85 & 2.50 \\
21 & 3.05 & 2.13 & 46 & 2.45 & 1.43 \\
22 & 2.25 & 2.38 & 47 & 3.25 & 3.00 \\
23 & 3.00 & 2.00 & 48 & 3.05 & 2.14 \\
24 & 1.75 & 2.50 & 49 & 3.30 & \\
25 & 3.30 & 3.13 & 50 & 3.40 & \\
\hline
\end{tabular}

All 50 participants in the study demonstrated a level of full-range leadership by scoring at or above a " 1 " in both transactional and transformational leadership before any other categorizing took place. The descriptive data in Table 3 indicated transformational leadership tendencies, with a tighter standard deviation, but continued to support the argument made by Avolio (2011). 
TABLE 3

DESCRIPTIVE DATA ON TRANSFORMATIONAL AND TRANSACTIONAL LEADERSHIP (MLQ SURVEY)

\begin{tabular}{llllll}
\hline & $\mathrm{N}$ & Mean & Median & Mode & SD \\
\hline Transformational & 50 & 3.00 & 3.00 & 2.90 & .48 \\
Transactional & 50 & 2.41 & 2.38 & 2.37 & .58 \\
\hline
\end{tabular}

TABLE 4

TRANSACTIONAL LEADERSHIP TENDENCIES

\begin{tabular}{ll}
\hline $\begin{array}{l}\text { Participants with Transactional } \\
\text { Leadership Tendencies }\end{array}$ & Average Likert Score \\
\hline 1 & 3.63 \\
2 & 2.38 \\
3 & 2.50 \\
4 & 3.00 \\
5 & 2.50 \\
\hline
\end{tabular}

TABLE 5

TRANSFORMATIONAL LEADERSHIP TENDENCIES

\begin{tabular}{llll}
\hline $\begin{array}{l}\text { Participants with } \\
\text { Transformational } \\
\text { Leadership Tendencies }\end{array}$ & $\begin{array}{l}\text { Average Likert } \\
\text { Score }\end{array}$ & $\begin{array}{l}\text { Participants with } \\
\text { Transformational } \\
\text { Leadership Tendencies }\end{array}$ & $\begin{array}{l}\text { Average Likert } \\
\text { Score }\end{array}$ \\
\hline 1 & 2.65 & 24 & 3.25 \\
2 & 2.90 & 25 & 2.89 \\
3 & 3.75 & 26 & 2.80 \\
4 & 3.50 & 27 & 2.40 \\
5 & 2.70 & 28 & 3.00 \\
6 & 3.55 & 29 & 3.45 \\
7 & 3.40 & 30 & 2.90 \\
8 & 2.90 & 31 & 3.40 \\
9 & 3.55 & 32 & 2.75 \\
10 & 3.20 & 33 & 3.00 \\
11 & 2.40 & 34 & 3.26 \\
12 & 2.35 & 35 & 1.90 \\
13 & 3.30 & 36 & 3.60 \\
14 & 2.65 & 37 & 4.00 \\
15 & 3.85 & 38 & 2.70 \\
16 & 3.20 & 39 & 3.05 \\
17 & 2.60 & 40 & 2.25 \\
18 & 2.53 & 41 & 2.85 \\
19 & 3.65 & 42 & 3.25 \\
20 & 3.05 & 43 & 3.05 \\
21 & 3.00 & 44 & 3.30 \\
22 & 3.30 & 45 & 3.40 \\
23 & 2.90 & & \\
\hline
\end{tabular}


The respective transactional and transformational tendencies, for each of the transactional and transformational identified respondents are shown above (See Table $4 \& 5$ ).

The dependent variable, levels of success, measured all 50 participants in Section 2 of the MLQ survey. Each participant answered "yes" or "no" to five definitions of success as defined by the research. The participants provided an answer to each question before advancing to the next. Unlike Section 1 of the survey, the participants did not have the option of deferring the question or answering "not sure" to the question.

TABLE 6

LEVELS OF SUCCESS SCORE: DESCRIPTIVE DATA

\begin{tabular}{llllll}
\hline & $\mathrm{N}$ & Mean & Median & Mode & SD \\
\hline Transformational & 45 & 4.07 & 4 & 5 & 1.14 \\
Transactional & 5 & 2.40 & 3 & 3 & 1.52 \\
\hline
\end{tabular}

Figure 1 shows the scores grouped by frequency of responses. The descriptive data between the two groups' levels of success as shown in Table 6 suggested a stronger tendency toward transformational leadership in all descriptive categories.

FIGURE 1

\section{LEVELS OF SUCCESS}

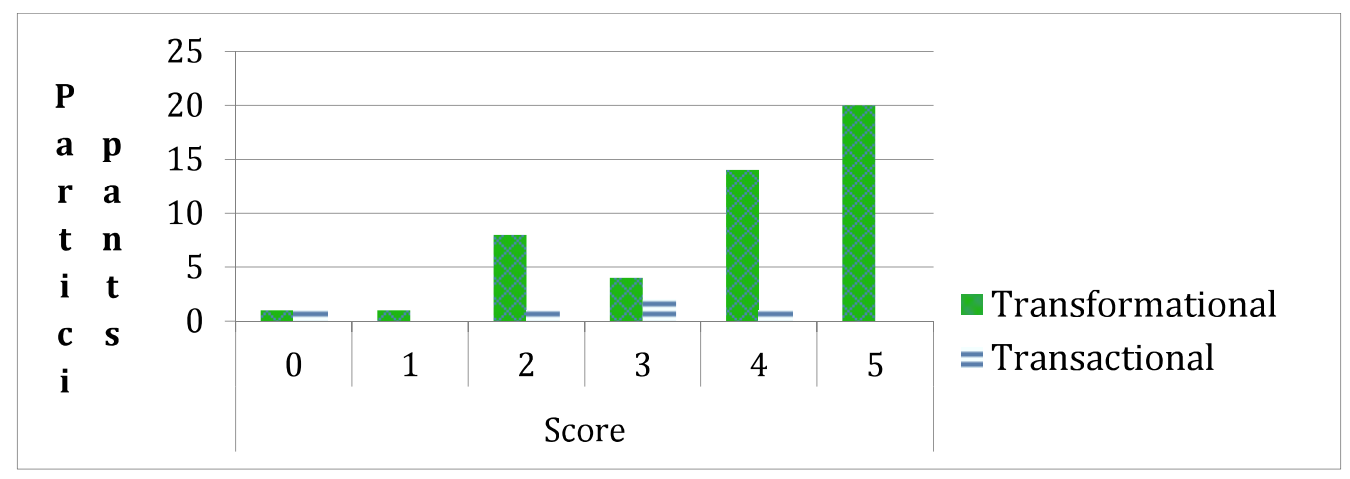
$0-5$.

Frequency of scores within the two leadership groups spread across the numerical success range from

\section{DISCUSSION \& CONCLUSION}

The primary research question asks, "Is there a significant relationship between the various degrees of success of selected national franchisees and the assessed leadership styles of the transformational and transactional leadership as perceived by the leaders?" The levels of success are defined by the researcher, and the leadership style is determined to be either transformational or transactional. To answer the research question, franchise leaders of the sample population responded to 28 questions from a Multileadership Questionnaire (MLQ) designed to measure the leaders' tendency toward transformational and transactional leadership. The study also provides a discussion and interpretation of the data on the dominant leadership style and its correlation with demographics and levels of success.

Of the 50 leaders who participated in the study, 45 show a tendency toward transformational leadership while only five display transactional leadership tendencies. Each franchise leader answered 28 mixed leadership questions using a Likert scale format. The scaled responses show leadership tendency toward transformational and transactional. The 45 transformational leaders yield a higher average on the 
transformational questions in comparison to the transactional questions answered. Likewise, the five transactional leaders yield a higher average on transactional questions. The responses were catalogued before studying the correlation with the levels of success and before determining whether there is a significant difference between the two leadership styles. All the leaders in the study average at least a score of "1" or greater, suggesting characteristics of full-range leadership.

Both leadership styles promote success in franchises, and the data gathered through the MLQ survey reflects the leaders' success level. However, the overwhelming number of leaders with transformational tendencies indicates that these franchise leaders must believe transformational qualities are in line with what their followers and associates search for in a leader. For instance, Stevens (2011) indicated that transformational leadership provides a greater sense of personal fulfillment and satisfaction for both the leader and employee.

The franchise organization experienced its own form of transformation on a macro-economic level. Prior to the financial meltdown in 2008, the franchise organization represented one major shipper that is no longer a domestic carrier (DHL Express) but fostered widespread franchisee success. The franchise corporation replaced the DHL Express book of business with United Parcel Service, but this collaborative business model has only seen moderate success levels. Many of the successful franchisees retreated from the business or downsized to accommodate for the weakened economy.

One theory may explain how the 2008 economic event may have contributed to the rise of leaders with transformational tendencies. During healthier economic times, leaders may have more financial freedom to reward followers for positive performance (a transactional leadership trait), yet during recessionary periods, leaders have more reason to exercise transformational leadership skills in support of future prosperity

In times of technological, social, and political change, the need for transformational leaders is more valuable than it has been in the past (Warrick, 2011). With downsizing, cutbacks, uncertainty, and ensuing competition, having a transformational leader at the top of an organization increases a company's chance of success (Warrick, 2011). Warrick suggested that while transformational leadership is imperative for the success of an organization, it is not clear what skills are needed to carry out this type of leadership. In order for an organization to thrive in tomorrow's world, there needs to be collaboration between transformational leadership and organizational development, as both are interrelated.

One may infer that leaders with only a slightly greater tendency of transformational leadership over transactional tendencies could translate into a comparatively greater level of success. In fact, the descriptive data from the MLQ survey in Section 1 indicates the difference in mean is .59 with transformational leaders at 3.0 and transactional leaders at 2.41. As such, the findings may contradict what the literature tells us regarding transactional leadership qualities. As an organization that measures itself through metrics using shipping data, numbers, and percentages to forecast success and economic outcome, transformational leadership should not outperform transactional leadership so profoundly

The results of the data analysis show critical differences between the levels of success between transformational and transactional leadership. The most apparent disparity is in the raw numbers within the sample. The entire sample of the population includes 50 participants; and 45 of the 50 exhibit transformational leadership tendencies while only five show transactional leadership tendencies.

While the results are consistent with the theory on full-range leadership in that all 50 participants scored greater than 1 on the Likert scale in the first section of the leadership survey, the number of transformational leaders is overwhelmingly dominant. The t-test delivered an alpha level of .004 when comparing the mean of the two groups, with a threshold of .05 or less for determining a significant difference.

Unlike the relationship between success levels and leadership style, the secondary analysis using only the dominant style tested against demographics has a different result. The 45 transformational leaders were sorted using four demographics and tested for significance between binary groups (gender, age, education, size of franchise). The independent variable is transformational leadership and the dependent variables are the four demographics: gender, age, education, and size of franchise. For example, the mean of levels of success were tested between all males and females within the transformational leadership 
group. An alpha level of .05 or less was used to test for a significant difference. A t-test was used for demographic analysis. The same procedure was applied to the three remaining demographic groups. The numbers of participants within the demographic groups are not as drastically different as they were in the initial testing groups. The results of the t-test at each of the four demographic groupings show no significant difference at the .05 alpha levels.

The results of the study suggest that leadership is valuable and has an influence on success and business longevity, but the demographics of the leader is of little importance. However, these data should be used cautiously and only applied to franchise organizations of similar design.

The study was structured to show that some franchising organizations have the latitude for entrepreneurship, and they are plagued with the same problems all small businesses face in the wake of competition and troubled economies. Understanding leadership at the franchisee level has its merit, and like many small and large companies, franchises need effective leadership at every level for success to exist and perpetuate.

\section{REFERENCES}

Avolio, B. J. (2011). Full range leadership development (2nd ed.). Thousand Oaks, CA: Sage Publications.

Avolio, B. J., \& Bass, B. M. (2004). Multifactor leadership questionnaire: Third edition manual and sampler set. Redwood City, CA: Mind Garden

Bann, C. L. (2009). An innovative view of the entrepreneur through exploration of the "lived experience" of the entrepreneur in startup of the business. Journal of Business \& Economics Studies, 15(2), 62-69.

Bass, B. M. (1997). Personal selling and transactional/ transformational leadership. Journal of Personal Selling \& Sales Management, 17(3), 19-28.

Bass, B. M. (2003). Power to change: A conversation with Bernard M. Bass. Face to Face, 23(2), 9-11.

Bass, B. M., \& Avolio, B. J. (1990). Training and development of transformational leadership for individual, team, and organizational development. In R. W. Woodman \& W. A. Passmore (Eds.), Research in organizational change and development. Greenwich, CT: JAl Press.

Dickie, T. S. (1992). The development of a business method. Franchising in America, 2, 1840-1980.

Franchising history-Continuing excellence. (2010). Franchising World, pp. 47-49.

Franchising your business. (2004). In D. Irwin (Ed.), Building Your Business Pocketbook (pp. 147-157). London, UK: Thorogood Publishing.

Gerber, M. E. (1995). The e-myth revisted: Why most small businesses don't work and what to do about it. New York, NY: Harper Collins.

Ismail, A., Mohamad, M., Mohamad, H., Rafiuddin, N., \& Zhen, K. (2010). Transformational and transactional leadership styles as a predictor of individual outcomes. Theoretical \& Applied Economics, 17(6), 89-104.

Kouzes, J. M., \& Posner, B. Z. (2007). The leadership challenge. San Francisco, CA: Jossey-Bass.

Lafontaine, F., \& Blair, R. D. (2005). The evolution of franchising and franchise contracts: Evidence from the united states. Entrepreneurial Business Law Journal, 3(2), 383-433.

Lafontaine, F., \& Shaw, K. (1997, March). Franchising growth in the US market: Myth and reality. Proceedings of the 11th Conference of the Society of Franchising, Orlando, FL.

Ling, Y., Simsek, Z., Lubatkin, M. H., Lyon, E., \& Viega, J. F. (2008). Transformational leadership's role in promoting corporation entrepreneurship: Examining the CEO-TMT interface. Academy of Management Journal, 51(3), 557-565.

Mellewigt, T. E., Ehrmann, T., \& Decker, C. (2011). How does the franchisor's choice of different control mechanisms affect franchisees' and employee-managers' satsifaction? Journal of Retailing. doi:10.1016/j, jretai.2011.01.001.

Morhart, F., Herzog, W., \& Tomczak, T. (2011). Turning employees into brand champions: Leadership style makes a difference. Gfk-Marketing Intelligence Review, 3(2), 35-43. 
Northouse, P. (2010). Leadership (5th ed.). Thousand Oaks, CA: Sage.

O'Grady, T. M., \& Malloch, K. (2011). Quantum Leadership (3rd Ed.). Sudbury, MA: Jones \& Bartlett Learning.

Shane, S. (1998). Research notes and communications making new franchise systems work. Strategic Management Journal, pp. 697-707.

Stanworth, J., Purdy, D., English, W., \& Willems, J. (2001). Unravelling the evidence on franchise system survivability. Enterprise and Innovation Management Studies, 2(1), 49-64.

Stevens, C. W. (2011). Using transformational leadership to guide an organization's success. Employment Relations Today, 37(4), 37-44. doi:10.1002.ert.20319

Warwick, D. D. (2011). The urgent need for skilled transformational leaders: Integrating transformational leadership and organizational development. Journal of Leadership, Accountability \& Ethics, 8(5), 11-26.

Watson, A., \& Johnson, R. (2010). Managing the franchisor-franchisee relationship: A relationship marketing perspective. Journal of Marketing Channels, 17, 51-68.

Zenovia,C. P., \& Maier,V. (2011, Winter). Entrepreneurship versus Intrapreneurship. Journal of Rivista de Management Comparat International, 5, 971-976. 


\section{APPENDIX A}

\section{MULTIFACTOR LEADERSHIP QUESTIONNAIRE}

\section{Transformational Leader Proclamations:}

1. I re-examine critical assumptions to question whether they are appropriate.

2. I talk about my most-important values and beliefs.

3. I see differing perspectives when solving problems.

4. I talk optimistically about the future.

5. I instill pride in others for being associated with me.

6. I talk enthusiastically about what needs to be accomplished.

7. I specify the importance of having a strong sense of purpose

8. I spend time teaching and coaching.

9. I go beyond self-interest for the good of the group.

10. I treat others as individuals rather than just as a member of a group.

11. I act in ways that build others' respect for me.

12. I consider the moral and ethical consequences of decisions.

13. I display power and confidence.

14. I articulate a compelling vision of the future.

15. I consider an individual as having different needs, abilities, and aspirations from others.

16. I get others to look at problems from many different angles.

17. I help others to develop their strengths.

18. I suggest new ways of looking at how to complete assignments.

19. I emphasize the importance of having a collective sense of mission.

20. I express confidence that goals will be achieved.

\section{Transactional Leader Proclamations}

1. I provide others with assistance in exchange for their efforts.

2. I focus attention on irregularities, mistakes, exceptions, and deviations from standards.

3. I discuss in specific terms who is responsible for achieving performance targets.

4. I make clear what one can expect to receive when performance goals are achieved.

5. I concentrate my full attention on dealing with mistakes, complaints, and failures.

6. I keep track of all mistakes.

7. I direct my attention toward failures to meet standards.

8. I express satisfaction when others meet expectations. 